\title{
The Vagaries of Therapeutic Globalization. Fame, Money and Social Relations in Tibetan Medicine
}

\author{
Laurent Pordié ${ }^{1}$ \\ ${ }^{1}$ National Centre for Scientific Research (CNRS-CERMES3), Paris, France. \\ Correspondence: Laurent Pordié, Cermes3, Campus CNRS, 7 rue Guy Môquet, 94800 Villejuif, France.
}

Received: December 11, 2015

Accepted: December 29, 2015

Available online: January 14, 2016

doi:10.11114/ijsss.v4i2.1303

URL: http://dx.doi.org/10.11114/ijsss.v4i2.1303

\begin{abstract}
Studies of the international diffusion of Asian medicine tend to overlook the social mechanisms involved in the transnational circulation of therapists. This article, built around the biography of a female practitioner of Tibetan medicine, demonstrates that upward social mobility gained through individual involvement in the NGO sector allows for the mobilization of transnational networks which sometimes offer travel opportunities in return. In the Himalayan region of Ladakh, the main reason that practitioners travel the world is through projects aiming to improve the local conditions of Tibetan medicine. Contrary to common assumptions, these journeys abroad do not primarily consolidate social status, economic capital and medical legitimacy for Asian medical practitioners; they also bring in their wake ambivalence in individual status. This is because, in the cultural context of Ladakh, gaining fame and money too rapidly or too visibly is seen as deeply problematic. This article examines these tensions and opens up research paths on the social logics and local implications of both regional development and therapeutic globalization.
\end{abstract}

Keywords: Transnational mobility; Local development, Fame; Money; Social frictions; Tibetan medicine

\section{Introduction}

Originally found in the vast regions comprising populations linked by the Tibetan language, culture and religion, ${ }^{1}$ the learned medicine of Tibet is today a global phenomenon. The logics of the neo-liberal economy, policies favouring export and the renewed aspirations of the practitioners have contributed to a redefinition of the modes of production of Tibetan medicine, and have helped to establish it internationally. Sowa Rigpa, the "science of healing" (gso-ba rig- $p a^{2}$ ), has been part of the global market for alternative therapies ever since, with a significant share in China itself (Craig and Adams 2008, Saxer 2013), benefiting as well from the positive image of Tibet prevalent in the West and from the international craze for non-biomedical treatments.

The entry of Tibetan medicine into the world market has provided opportunities for the practitioners themselves to circulate globally, including those belonging to regions less directly affected by these developments. However, little is known on the social mechanisms involved in such individual mobility. The work by Mei Zhan (2009) on transnational Chinese medicine is a notable exception. This author used biographical accounts as a way of examining the specificity of translocality. She discusses the biographies of women practitioners from Chinese medical lineages and, by recounting the stories of their lives and careers, examines the transnational gender politics of traditional Chinese medicine (ibid: 145-174). This work also provides details on the biographies of practitioners who have migrated from China to the San Francisco Bay Area to illustrate how, by producing "clinical miracles", they not only achieve personal success and fame, but also fight for a foothold for traditional Chinese medicine in mainstream American medicine (ibid.: 92, 109-110). The only work relating to the international diffusion, if not globalization, of Tibetan medicine based on detailed individual itineraries is an MA thesis on a renowned family of Tibetan practitioners originating from Buryatia (Saxer 2004) - some aspects of which have been later revised and published (Saxer 2010). ${ }^{3}$ The author traced the

\footnotetext{
Note 1 This medical practice is found along the Himalayan range, in Pakistan (Baltistan), India (Ladakh, Himachal Pradesh, Sikkim and Arunachal Pradesh), in Nepal (Mustang, Dolpo, the region around Mount Everest), the People's Republic of China (the Tibet Autonomous Region, Yunnan, Sichuan, Gansu, Qinghai, Inner Mongolia) and in Bhutan as well as in Mongolia and Buryatia. Ladakhi practitioners believe that Tibetan medicine arrived in their territory in around the 10th or 11th centuries.

Note 2 In this article, Tibetan and Ladakhi terms are transliterated according to the scheme proposed by Wylie (1959).

Note 3 The data presented in this work was collected by the author in parallel with the shooting of a brilliant documentary film on the subject, which was released the following year (Saxer 2005). The combination of these two works constitutes an excellent example of visual anthropology.
} 
international peregrinations of the Badmayev family over 150 years and four generations, through Russia, Poland, Switzerland, and the United States. We learn that one of the family members established the first Tibetan medical practice in Europe sometime in the early 1860s (Saxer 2004: 15-17) and that a Badmayev descendant inspired the establishment of the Swiss (Tibetan medicine) pharmaceutical company, Padma AG, in the late 1960s (ibid.: 65). There are other works that narrate the personal histories of some reputed Tibetan doctors who were forced to leave their country in the wake of the Chinese occupation. However, while these texts do serve to illustrate their remarkable and often difficult journeys, as well as the dramatic situation in Tibet (Avedon 1997 [1984], Josayma and Dhondup 1990, Tsering 2005), they do not link such journeys to the international diffusion of Tibetan medicine, and even less to the logics of therapeutic globalization.

In spite of the increase in academic work on global Tibetan medicine (Janes 2002, Meyer 1986, Millard 2008, Vargas 2008) and the effects of globalization and the market on the medical practice (Craig and Adams 2008, Janes 2001, Pordié 2011, Samuel 2001, Saxer 2013), there is a relative dearth of writing on the role of social mobility within the circulation of transnational Asian medicine. This paper presents a corrective by addressing the relations between, on the one hand, the social status gained by practitioners involved in projects arising out of international initiatives concerned with "medical culture" or "traditional health" in the Tibetan world and, on the other hand, the global mobility of Tibetan medicine practitioners. The articulation of these two domains of enquiry is a grey area in the literature which may be partly explained by the fact that a research subject of this kind seems at first sight to present a paradox: welfare projects focussing on Tibetan medicine have an explicitly local dimension, a fact which does not encourage a view of them as important players in the international diffusion of Tibetan medicine. These projects bring in their wake socially constituted networks of organizations and donors based in the West or in economically advanced Asian countries, networks which can be mobilized by the therapists to enable foreign travel. It is projects such as these that are the dominant factor in the international circulation of the Tibetan medical practitioners from Ladakh, ${ }^{4}$ a remote Himalayan region located in north-western India on the borders of both Pakistan and China.

It was in Ladakh that I met the woman I will call Dolma Tsering in the late 1990s. At that time, nothing suggested that she would one day travel the world, since she had neither the adequate social status nor the essential social network. Her life's journey, however, was later to lead her to distinguish herself amongst her peers and to acquire a high and coveted status. She belongs today to a category of practitioners who play a significant role in the social redefinition of institutional Tibetan medicine. Their activities are differentiated and diversified and include, for example, management of non-governmental organizations, environmental protection and the defence of intellectual property rights as well as research in the clinical, pharmacological, botanical, and philological domains. These practitioners make up a group that has emerged over the last twenty years in a new socio-political and economic environment, in an urban milieu or close to the social and political life of towns (Pordié 2008a). In this article, I refer to them as the 'elite'. Their aspirations go far beyond the medical field. New possibilities are open to them within and outside their medical universe, their regions and their societies. Travelling the world is one such possibility.

Back in her country, Dolma Tsering found herself in an ambivalent situation. While her travels had enhanced her social status, this was concomitantly challenged by her often envious counterparts who accused her of greed and opportunism. Individual mobility along and within global circuits and networks thus involves consequences that some authors have chosen to qualify as "frictions", to underscore relations of disjuncture (Appadurai 1990), conflicting social interaction that nevertheless produces movement and further effect (Tsing 2004), or again, uncertain processes in global interaction (Froystad 2009). In this paper, the kind of discomfort engendered by global processes is examined in the light of the difficult relationship found in the region between status, the making of money and social relations, as well as gender and ethnicity politics. The biographical itinerary of Dolma Tsering thus illustrates the way transnational flows are often marked by frictions; it also provides the materials to situate the analysis in the more general framework of the globalization of Tibetan medicine.

Studying the social mechanisms at work in the circulation of individuals involves delving into various sectors of social life and various levels of analysis. Local and global worlds and priorities intersect through the life of practitioners such as Dolma Tsering who truly straddle these domains, synchronically and/or diachronically, over the course of their careers. Examining the conditions of possibility and the social implications of the transnational circulation of Dolma Tsering therefore requires a double methodological exigency: special attention to the observation of small local units, and equal attention to the worlds that traverse them, worlds that in the process constitute and reconstitute them (Augé 1994). This will prove useful in our exploration of the role of 'local development' in the global diffusion of Tibetan medicine, as well as in our examination of questions of social and medical legitimacy and power relations within the

Note 4 Ladakhi practitioners of Tibetan medicine travel to foreign countries for at least two supplementary, but much less significant, reasons. Some of them have family ties with people settled in the West or in economically advanced Asian countries, and occasionally visit them there. International conferences provide another way to go abroad, but, to my knowledge at the time of writing, this has only been to Nepal and, very recently, to the UK. 
group studied. As a contribution to this agenda, I have chosen to follow the personal history of Dolma Tsering through a series of biographical and analytical vignettes.

\section{Making Money in Tibetan Medicine}

The exodus of thousands of Tibetans during the 1950s was a determining factor in the international spread of Tibetan medicine. The exiles were very dynamic, and quickly reconstructed their celebrated colleges of medicine in India. One of these, the Men-Tsee-Khang, ${ }^{5}$ is today the biggest institution of the Tibetan diaspora (Kloos 2008). Institutional Tibetan medicine has become a relatively lucrative business. In China, the period of reform that followed the Cultural Revolution also brought about profound transformations in Tibetan medicine. The Chinese government, wanting to integrate this medicine with scientific modernity, supported its development and provided opportunities for fresh directions. In particular, they encouraged the privatization of its practice and the export of medicines (Janes 1995 and 2001, Saxer 2013). Tibetan medicine has thus become a commodity in a burgeoning worldwide and very competitive healthcare market. The situation is much the same in Bhutan, where the pharmaceutical unit of the Institute of Traditional Medicine Services in Thimphu explicitly focusses on exporting medicines.

These developments have brought about profound changes in medical supplies at the national level. The post-socialist versions of a liberalized economy in Mongolia and in the Tibet Autonomous Region have caused the poorest in the population to be cut off from Tibetan medicine (Janes 1999 and 2001, Janes and Hilliard 2008). Elsewhere, the preparation of medicines and their components have been modified in order to penetrate Western markets. For instance, the clinics of the Tara Institute in Great Britain only produce plant-based medicines in accordance with a list of plants imposed by the British Government (Millard 2008), and mercury, proscribed in the West because of its toxicity, is excluded from medicinal preparations in some contexts in Asia (Aschoff and Tashigang 1997, Craig 2012: 151). Tibetan medicine is thus produced as a global commodity and consumed everywhere for its indigenous virtues (Janes 2002).

While this form of Tibetan medicine is today permeated throughout by capitalist logics, it does however embody moral (Buddhist) values and a particular vision of the world that exerts a particularly seductive power in Western societies. However, the very logics that render this medicine accessible in the West embody a kind of ideological and economic domination which is generally (most often, discursively) opposed by its Western supporters. These objections are made in Asia too. In India, the Men-Tsee-Khang stopped selling medicines to private clinics in the 1980s to discourage attempts at personal gain (Kloos 2013). More recently, the officials of the Tibetan Government in exile deplored the contemporary trends in Tibetan medicine. In 2003, during a talk given on the occasion of the forty-second anniversary of the Tibetan Medical and Astro Institute (Men-Tsee-Khang) in Dharamsala, the Prime Minister, Samdhong Rinpoche, and the Minister for Health and Finance, Lobsang Nyendak Sayul, expressed their profound disagreement with the business orientation of Tibetan medicine. The Prime Minister repeated his reservations in 2006 at the International Conference of the Central Council of Tibetan Medicine in Dharamsala, exhorting practitioners not to become too involved in commercial affairs. He added a moral stance to his remarks by encouraging physicians to be compassionate, and "not to become commercialised medical professionals" (Chauhan 2006). These men addressed their forebodings concerning the future of institutional Tibetan medicine in general and the development by practitioners of private clinics in particular, seeing therein a threat to the survival of Tibetan culture.

Their remarks underlined not only the links between Tibetan medicine and 'cultural survival' in exile (Kloos 2010), but also, and most significantly for this article, a problematical sentiment amongst Tibetans about the rapid or too visible acquisition of status or wealth. For Martin Saxer's interlocutors in the Tibet Autonomous Region of China (2013), Tibetan medicine is an antithesis of the world of Chinese business. ${ }^{6}$ One of them thus said:

There was a businessman, a Chinese. He asked me if I wanted to work with him to build this school and I agreed. Then, he asked me, 'How are we going to divide the income?' And my answer was that there would be no income. So he asked how I could think of building a school that would not generate any income. And what is more, he asked what good it was if there was no income. My answer was that it was good for my Tibetan culture (cited in Saxer 2013: 2).

This feeling becomes all the more acute when it concerns the practitioners of Tibetan medicine, or amchi. In general in the Indian Himalayas, rural amchi are not wealthy. They do not see Tibetan medical practice as a strong source of income and nor do the villagers. And indeed, solely from an economic standpoint their practice is hardly viable, if at all

Note 5 The Men-Tsee-Khang (sman rtsis khang) was originally founded in Tibet in 1916 by the 13th Dalai Lama, and was re-established in India by Tibetan exiles in 1961. It is located in upper Dharamsala at McLeod Ganj, the township that is home to the government of the present Dalai Lama. See Kloos (2008) for details.

Note 6 Writing about a Chinese minority nationality traditional practitioner and seller of natural pharmaceuticals in China, Judith Farquhar and Lili Lai (2014: 21) remark that "in the free-wheeling market environment of China today, any sort of expertise can be a commodity, and its vendor has a near-inviolable right to make money from it". 
(Besch 2007, Blaikie 2009, Pordié 2002). What is more, in the Ladakh region these practitioners are generally perceived by their fellow citizens according to idealistic models, with emphasis on qualities such as honesty, sincerity, and compassion (Besch 2006: 102-110, Kuhn 1994, Pordié 2007) - standards which must disqualify some of them. The amchi themselves cite certain behavioural and moral codes that they must follow in order to improve their medical practice. $^{7}$ The "qualities" most often cited are compassion (snying rje), respect for living beings, honesty and generosity. They also believe that helpfulness, respect for others, an open smile, candid words and a "good heart" (sems bzang) are very important. The development of altruistic qualities occupies a central place, and conditions, perhaps more than the other qualities, the healing power of the therapist. ${ }^{9}$ While moral organization and social behaviour are largely secular among laymen (Pirie 2006), in the case of the amchi, the moral and ethical dimensions of medical practice are clearly influenced by Buddhism.

The accumulation of capital by Tibetan medical practitioners and the subsequent rise in status this brings about are commonly seen to be incompatible with the ideas just enumerated since they may imply greed and boastfulness. Most importantly, Ladakhi society at large is characterized by a relative equality among the majority of its people (Pirie, 2007), and differences - in wealth or opinions, for example - are generally concealed from the public. Conspicuous disparities among individuals are considered potentially damaging to social equilibrium.

\section{A Marginalised Female amchi in Ladakh}

Dolma Tsering belongs to a family of pastoral nomads who fled Tibet for India at the end of the 1950s due to the troubles caused by the Chinese invasion. She was born in 1970 in Kharnak, on the high plateaus of the Ladakhi Changthang. As is shown on her identity card (Identity Certificate, Govt. of India), the place and date of her birth made Dolma Tsering an Indian citizen of Tibetan origin. ${ }^{10}$

For many years, her household (drong-pa) raised yaks and goats, moving in groups of several tents (rebo) in a regular rhythm towards new pastures. The difficult conditions of existence of these populations, and the hope of gaining a better life, have significantly contributed to the massive rural exodus over the last forty years (Goodall 2004, Dollfus 2004). Numerous Ladakhi and Tibetan families were established in Choglamsar, a town situated on the immediate periphery of Leh, the capital of Ladakh, and it was here, in the Tibetan settlement 100, that Dolma Tsering lived during her adolescence.

She was a good student and easily passed the grade $10+2$. This examination, which certifies twelve years of schooling, allowed her to envisage higher education. Dolma Tsering decided to study Tibetan medicine, moved by the deplorable sanitary conditions of the nomad community into which she was born, she explains. Neither of her parents were Tibetan medical practitioners. She joined the specialized department of the Central Institute of Buddhist Studies (CIBS) in Choglamsar in 1988. The curriculum and the examinations of this institution, which is answerable to the Central Government of India, are supervised by the Tibetan authorities of the prestigious College of Medicine and Astrology at Dharamsala (Men-Tsee-Khang). Dolma Tsering was part of the first graduate class of the school.

She studied for five years followed by twelve supplementary months of practical training. Her internship took her to the Housing Colony in Leh, in the clinic of her former professor at CIBS. ${ }^{11}$ Dolma Tsering was awarded the Kachupa diploma ( $\left.d k a^{\prime} b c u p a\right)$ in 1994, known officially in India as Bachelor of Tibetan Medicine and Surgery (BTMS), the highest degree of institutional training in Tibetan medicine which very few practitioners in Ladakh hold. ${ }^{12}$

Dolma Tsering then consulted for a year in a Tibetan Medical Camp near to her home, followed by two supplementary years in the second clinic of her former teacher in Leh. She founded her own clinic at the centre of Choglamsar, near the bus station, which gave her a certain degree of visibility. The inhabitants appreciated her services: Dolma Tsering, it began to be said, was an "amchi rgyala" (a good amchi).

She married a Tibetan soldier from the Indo-Tibetan Border Force in the second half of the 1990s. They had a son together then divorced a few years later. Dolma Tsering married for a second time in 2005 and had two more children,

\footnotetext{
Note 7 They very often recite to the letter the passages found in a $17^{\text {th }}$ century canonical text, the Gyud-zhi (Rgyud-bzhi), which lays down the ideal mental and behavioural qualities of the therapist according to a Buddhist ethical framework - especially Chapter 31 of the Explanatory Treatise (Bshad-pa'i rgyud) which describes the ideal therapist. For details, see Pordié (2007).

Note 8 "Good mind" is sometimes found as the literal translation of sems bzang, but the term "good heart" seems closer to the idea of sems bzang. Some authors also propose "heart-mind" as a translation of sems.

Note 9 Altruism is fundamental to Mahāyāna. It serves the double function of creating social links and universal solidarity leading to the good of all sentient beings. Altruism is an idea that involves both oneself and the other (bdag gzhan).

Note 10 Section 3 of the Synopsis of the Citizenship Act, 1955, the latest amendment of which was applied in June 2005 and concerned Indian citizenship, stipulates: "A person born in India on or after January 1950 but before $1^{\text {st }}$ July 1987 is a citizen of India by birth irrespective of the nationality of his parents" (Internet site of the Ministry of Home Affairs: http://www.mha.nic.in/).

Note 11 For details on the CIBS and on the plurality and interaction of learning modes in Ladakh, including that of a temporary school presented later in this text, see Pordié and Blaikie (2014).

Note 12 Only fifteen people hold the Kachupa diploma out of a total of about 150-160 amchi in the region.
} 
in 2006 and 2008.

This woman remained in Choglamsar for a long time, isolated from the urban amchi community. All the practitioners who held important positions in Leh, either in the Government or in associations, and all of them Ladakhis, knew Dolma Tsering. However, although she possessed the required local reputation and level of medical education necessary to become a member of the elite, these did not prove sufficient. Callously ignored and marginalized for many years, Dolma Tsering was never, for example, recruited as a teacher, or even as a participant at the training seminars regularly organized in Leh by the Health Department or the main Ladakhi association of amchi between 1988 and 1999.

In a male-dominated milieu, being a woman of Tibetan origin bringing up a child without a husband did not help her to integrate.

\section{On the Relations between Ladakhis and Tibetans}

The Ladakhi amchi maintain polite but distant relationships with Tibetan exiles in India whom they consider to be very proud and haughty. "The Tibetans think themselves superior. (...) I feel more gratitude for my eight generations of [Ladakhi] amchi ancestors than for my Tibetan teachers at the Men-Tsee-Khang," remarked the professor of Tibetan medicine at the CIBS. According to another amchi, a government official, "the Tibetans are superior to Indians [he naturally includes Ladakhis in that group]. They are everywhere in India and do what they like. No one can control them." The Ladakhi amchi also think that the Tibetans are more interested in accumulating capital than in Buddhist precepts. They thus make a moral judgement concerning the Tibetans. A feeling of inferiority however characterizes many practitioners of Ladakh. The fact that Tibet is the historical centre of Tibetan medicine, as well as the remarkable structural developments and the international success of Tibetan medicine in exile certainly induce this feeling.

The amchi of Ladakh, obviously very impressed by the Tibetans, nevertheless differentiate themselves from them. In their idiom they never qualify their medicine as "Tibetan". As elsewhere in the cultural area of Tibetan influence, the vernacular term used to designate this medicine is Sowa Rigpa (gso-ba rig-pa). When conversing with foreigners or communicating through websites or informative brochures, most non-Tibetan practitioners, westerners aside, claim their medicine to be distinct for reasons of local identity. The denomination "Tibetan medicine" is sometimes used to render the practices more understandable to westerners, but the regional specificities are usually quickly formulated, and in a sense reflect the anthropological variability of Tibetan medicine (Pordié 2008a: 4-5).

The Ladakhis claim to have conserved a tradition that the exiles have lost. A tradition characterized by the existence of medical lineages, gyudpa (brgyud-pa, syn. rgyud-pa) and by non-institutional educational modalities. They thus put forward their distinct identity, which is however perceived by some Tibetans as belonging to history: for them, the existence of gyudpa amchi is a thing of the past. This is true of the Tibetan exiles in India, where the overwhelming majority of doctors trained by the Men-Tsee-Khang do not belong to lineages, but it is completely untrue in the case of Ladakh. When a Tibetan thus brought up the history of Tibetan medicine during a seminar organized in Leh in 2003 , his allocution generated a very vibrant reaction from an audience made up mainly of Ladakhis.

The Tibetans exiles also regard the Ladakhi amchi as lazy. They point out their lack of formal organization ${ }^{13}$ and consider them for the most part to be practitioners of a lesser calibre. We hear, for example, amongst the Tibetan exiles in Dharamsala that the Ladakhi village amchi are not strictly speaking amchi, that is to say, not properly trained therapists who could adequately represent Tibetan medicine. A Tibetan amchi of Men-Tsee-Khang, ironically employing a terminology sometimes used in English by Ladakhi practitioners to designate their medicine ("amchi medicine"), remarked: "the Ladakhis don't practise Tibetan medicine, they practise amchi medicine... You understand?" (24 ${ }^{\text {th }}$ June 2000). The exiles generally consider themselves to be explicitly superior.

\section{Upward Social Mobility and the NGO Sector}

Dolma Tsering's status only began to be recognised by the Ladakhi amchi in 1999, though not without difficulty. A European association, which had started working in Ladakh the preceding year, raised sizeable funds in order to establish new programmes, amongst them a school of Tibetan medicine. I was amongst those involved with that organization, and, together with my colleagues, set out to look for an amchi with a reputation for competence, who would be employed full time as a professor in Tibetan medicine at the school. Perhaps predictably, members of the Tibetan medical elite showed no interest in the offer, as they either had private practices or held secure positions in the Government. One of the few institutionally-trained amchi available, however, pointed the group to Dolma Tsering, and the members paid her a visit.

"I did not know you but you knew me," recalled Dolma Tsering in 2002. "Dorje was also present. (...) He

Note 13 However, it is worth mentioning that the 2010 official recognition of Sowa Rigpa in India is a struggle that the institutional amchi of Ladakh began in the early 1990s, and achieved nearly two decades later, by forming an alliance with other regional groups (but no Tibetan exiles), under the leadership of a prominent Ladakhi amchi. 
asked me if I was interested in a job teaching Tibetan medicine for six months over the winter. At first I refused. My son was very young at that time, just four or five. I had to take care of him and could not agree to take charge of the teachings (...) I said too that I was not capable of teaching and that it would be better to look for another amchi, someone more experienced than me. This is what I said. I did not have enough time to spare because I had to be busy with my clinic at Choglamsar. You left and I said again that there were better amchi than me. (...) Two weeks later you were back. ${ }^{14}$ I thought about your proposition. I talked to my parents. At that time my father was still alive. He said that I should take a chance and that I would have the opportunity to develop my knowledge in this way. He added that if I felt unable to teach, that would mean a waste of time and a waste of money for the NGO (...) So I said that I would have to think it over."

Two weeks later, Dolma Tsering accepted the job offer, and in the autumn of 1999 she was given the title of Medical Coordinator at the association's office in Ladakh. There was strong opposition from some influential amchi against the recruitment of a Tibetan. One of these, her former classmate at the CIBS, complained in June 2000 that the post should have been given de facto to a Ladakhi person. Counsellors and experts of the amchi association of Ladakh had reservations regarding the foreign organisation's choice, and continued to voice them for months. ${ }^{15}$ Unlike the other members of her new association, Dolma Tsering was not, for example, invited to the general assembly of the amchi of Ladakh in November 1999, an important event that was supposed to gather most of the regional practitioners.

The Tibetan amchi took up her duties in the following winter. She lived at the school with her son. She worked extremely hard, preparing her courses before the students got up in the morning, looking over their work in the evenings, and spending time with her son during the short breaks. Being thus invested in her responsibilities, Dolma Tsering was able, gradually, to bolster her self-confidence.

From 2000 onward, Dolma Tsering took on full responsibility for the winter activities of a newly-founded local association, which I will call XYZ for reasons of anonymity, established as the local branch of the European organization. ${ }^{16}$ She often complained of the frequent absences and the general laxness of her Ladakhi colleagues, the director and executive secretary, to whom she gave a subordinate position.

"I have more responsibilities than Dorje or Tashi, far more... During the winter months I was with the students day and night. Dorje and Tashi just kept office hours. And Tashi did nothing at all in the winter; he is lazy. If I compare myself with them I was doing twice the work (...) I had no time for my own clinic at Choglamsar, just an hour in the morning and an hour in the evening, and then only in the summer. I asked them to come and help me in winter. Tashi never came at all, not for a single evening. (...) I was always on my own with the students, six months of the year with them! Tashi said he had to take care of his family. He said that he had a lot of work in the house. Me too, and my mother is old. (...) If I hadn't been there, XYZ would not have functioned. It is as simple as that. It is definitely during the winter that it is hard. In summer I have no problem. (...) I take more responsibility for XYZ than for my own family. My mother says that I am doing very little in the house. There is plenty of work at my place. I have to find replacements for myself for the cows and the cleaning. (...) I fulfil my functions rigorously and with determination. It is for the students and for Tibetan medicine. (...) I told Dorje and Tashi several times that they must work as much as I do otherwise I would leave" (Extract of a discussion between the author and Dolma Tsering in $2002^{17}$ ).

Dolma Tsering was not only in charge of the medical studies in winter for twenty- one students over four years from 1999 to 2002, and of an annual week of summer camps focusing on plant identification, she also had an equally crucial role in the planning and implementation of a number of other projects for the benefit of the rural populations of Ladakh. Although she was less present in her own clinic, she became an indispensable member of the association. The functions of this amchi were greatly increased. She was involved in training projects, in establishing village clinics, and in

\footnotetext{
Note 14 Dawa Tashi, a Tibetan woman and a graduate of the CIBS, meanwhile refused the offer, asserting that Dolma Tsering was much more competent than she was.

Note 15 This association was formed in 1978 under the auspices of a high-ranking religious figure with great political power. Its activities have been relatively limited in the medical field stricto sensu, despite the more or less regular organisation of training workshops and the establishment of a modest clinic and a section for the manufacture of drugs. At the time of research, the most fundamental role of this association consisted of utilising its network of influence to ensure the promotion of amchi medicine amongst local authorities.

Note 16 The European association began its activities in Ladakh in 1998. Two years later, the Ladakhi team set up XYZ, an association which was officially registered under Indian law in March 2002 in the State of Jammu and Kashmir. While XYZ was responsible for the functioning of the programmes, the sponsoring organization took charge of certain aspects of its activities and of finance and direction.

Note 17 According to her colleague, Dorje, "Dolma Tsering is the core of the organization because she is the only person able to conduct the teaching of Tibetan medicine. Her abilities are ideal for that." He is also aware of Tashi's sometimes lax behaviour but emphasises that this fault is counterbalanced by his technical knowledge, his vivacity and his efficiency. As for Dorje himself, he says he is at ease organizing seminars, making contacts with people and teaching Tibetan grammar to student amchi. However, he would like to receive training of various kinds in order to acquire more knowledge. He feels inferior to his two colleagues because of that lacuna and refuses for that reason to take over the directorship of the organisation.
} 
medicinal plant conservation programmes. Her influence extended over new domains. ${ }^{18}$

The situation brought Dolma Tsering progressively to the forefront of the Tibetan medical scene in Ladakh. Her activities increased and diversified as her reputation became established. As the only amchi active within the organization and its teaching centre, responsible for medical programmes, generally held in esteem by her peers, and recognized through different awards, ${ }^{19}$ Dolma Tsering enjoyed very great visibility. Clearly, she did not owe her very swift progress within the regional Tibetan medical elite solely to the international status of her employer, nor to her title, nor, indeed, to her duties. As Marc Abélès wrote, to advance means proving oneself and not only occupying the territory (1995: 68). Dolma Tsering was teaching alongside reputed experts in the field. Her ability was there for every one to judge, and the board of directors of the principal association of Ladakhi amchi recognised her theoretical knowledge and pedagogical qualities. The situation had turned right around.

Now, Dolma Tsering has gained in status. She tends to be quiet in front of men, who completely rule this milieu, especially the renowned amchi who hold government positions or high status for reasons of age or lineage. She nevertheless continues to be regarded by her peers as an excellent practitioner. One of them told this writer in 2002: "The association of amchi has changed its opinions regarding Dolma Tsering. I am happy that she is at the school. (...) Comparing her to any Ladakhi amchi is unthinkable". Amchi today also emphasize her level of education even though this was not previously mentioned. Dolma Tsering regularly participates in large meetings and is now undeniably one of the noted amchi of the region.

Dolma Tsering's entry into the NGO sector was a determining factor in her upward social mobility. While under scrutiny by the amchi, she responded brilliantly to the testing of her qualities as a teacher and a doctor.

The constitution of associations of therapists is a recent phenomenon in the trans-Himalayan world; in the course of the last three decades it has greatly contributed to the social transformation of Tibetan medicine. In Ladakh, the creation of the first association, Ladakh Amchi Sabha, dates from the late 1970s. In 1984, a local organization, the Leh Nutrition Project (LNP), supported by the Save the Children Fund, UK, established a programme on Tibetan medicine for a period of twelve years. This project was the first large, professional intervention in this field at the regional level, and has contributed enormously to shaping the perception of urban amchi of the future of their medicine. The amchi then responsible for this programme has gradually won, in the course of his mandate, and for reasons very similar to those of Dolma Tsering, a great deal of appreciation from elite amchi.

It was not, however, until the middle of the 1990s, perhaps due to the influence of the LNP programme, that the elite Ladakhi amchi were collectively involved in what the practitioners themselves call the "development" of their medicine. Significantly, in current oral language, they use the English "development" but also the learned Tibetan term yar rgyas, which literally means "expansion/growth (rgyas) upwards (yar)". Chosen in the literate milieu to describe "development", yar gyas occurs very often in the discourse of elite amchi. "Development" qualifies different situations, relative to Ladakh's general economic development or to projects aiming at improving the conditions of practice of the therapists.

The amchi find the necessary tools in the associative sector to position themselves individually and collectively in contemporary Ladakh. Jean Michaud wrote more than twenty years ago that those responsible for NGOs in Ladakh, especially in the educational and environmental domains, made up an integral part of the "petite bourgeoisie" (1990). This remark somewhat reflects the situation today. The Ladakhi elites, noted Fernanda Pirie (2007: 41), belong to three categories: government officials and local politicians, persons of aristocratic status, and members of development organisations. The integration of amchi into local associations dedicated to the "development of Tibetan medicine" facilitates access to urban elites, grants a form of social recognition and a high status, which extend beyond the boundaries of the field of Tibetan medicine.

Conscious of her status, Dolma Tsering considered taking a government job by joining the Research Unit on Amchi Medicine as a Research Assistant in 2002 to replace one of its members who was about to retire. Her selection would have allowed her to integrate into one of the only structures of Tibetan medicine in Ladakh (with the CIBS which granted her diploma) answerable to the Central Government of India. Created in 1976 under the aegis of the Ministry of Health and Family Welfare in Delhi, the Research Unit was at the time of research placed under the Central Council for Research on Ayurveda and Siddha. This unit was involved very early on in clinical research (since 1979), in textual

Note 18 Since 2000, Dolma Tsering has been the editorial director of a trans-Himalayan journal of Tibetan medical education. During this period she organized several regional seminars. She supervised a health centre, and from 2003 participated in the installation of fifteen village clinics. Since 2001, she has been responsible for a clinic frequented by a large number of tourists, where she gives weekly lectures in English during the summer period. She has been involved since 2004 in a regional program for the preservation of medicinal plants, covering twenty villages. Dolma Tsering is also a favourite interlocutor for numerous visiting students from European and American universities.

Note 19 Between 1998 and 2002, the European organization and its members won nine prizes and distinctions in France and elsewhere in recognition of the activities carried out in Ladakh. The urban amchi of the region were kept regularly informed, since a prize meant the arrival of funds. 
studies and botanical identification and the cultivation of medicinal plants. It embodies the renewal of Tibetan medicine in Ladakh. Dolma Tsering wanted to extend her field of activity still further and to consecrate a part of her time to research.

Her application was however rejected. The official explanation for this action was based on her Tibetan origin and on the fact that, unlike the Ladakhis, she did not benefit from the status of Scheduled Tribes. ${ }^{20}$ The groups thus designated enjoy special concessions in such fields as higher education and employment. According to Dolma Tsering, however, that reason made no sense: she believed that she was denied the post simply because the person in charge of the unit "wanted as an assistant an amchi less competent than he was himself". From 2002 onwards, she remained actively involved with her NGO.

Over the years, Dolma Tsering has revised her aspirations and the idea she has of herself - we should bear in mind that in 1999 she had felt herself incapable of teaching Tibetan medicine. Buoyed by her subsequent performance, she considered in November 2009, for example, submitting an application for the Smanrampa (sman rams pa) diploma. Dolma Tsering explains that a candidate for this diploma, issued by the Men-Tsee-Khang of Dharamsala, must have at least ten years' experience and a certain number of publications in the Tibetan medical field. ${ }^{21}$ Currently, no amchi in Ladakh has a diploma higher than Kachupa, and Dolma Tsering could well be the first.

Dolma has been invited to Nepal twice where she gave several talks at international conferences on clinical practice, the development of Tibetan medicine, and environmental conservation. In 2002, she was invited by the World Wildlife Fund (WWF) and Unesco along with two reputed Ladakhi amchi. In 2004 she went back to Nepal by herself, where she was invited to give two talks on a theme explicitly focused on Tibetan medicine development in her region. Dolma Tsering presented her teaching methods in Tibetan medicine, followed by a more general reflection on the school project in which she had participated.

In 2005, this amchi was co-winner of an international prize awarded by a prestigious European foundation in recognition of her work in the preservation of medicinal plants in Ladakh.

The amchi who was vehemently opposed to her recruitment by her European employers six years earlier was also in charge of the Research Unit that had rejected her candidature. In 2005, however, this man revised his judgement and tried to persuade the woman amchi to leave the organization she was attached to, and to take in hand a dormant association that he had himself started at the end of the 1990 s. $^{22}$ She refused.

In the space of just a few years Dolma Tsering gained renown, a fundamental social criterion in the regions of Tibetan culture. ${ }^{23}$ She had undeniably become a figure to reckon with in the Tibetan medical elite of Ladakh.

\section{Transnational Networks, Donors and Travels}

Dolma Tsering's local status alone did not provide her with the opportunity to travel abroad. In Ladakh, membership of a professional association, coupled with high social status, is a necessary (but by no means sufficient) condition for a medical practitioner to consider himself or herself qualified for foreign travel. The international mobility of therapists also demands, as a prerequisite, that they should be inserted into wider transnational social networks. And it is the participation of the amchi in their professional NGO network within Ladakh that provides the best means to access the network of foreign "sponsors" - who they meet through "tourists' clinics" 24 and other activities promoting Tibetan medicine.

The term "sponsor", chindak (sbyin bdag), is traditionally applied to individuals or groups, such as households, who provide donations (patronage) in particular contexts, such as religious festivals, the construction of bridges over rivers, or the repair of access roads to villages. In the Ladakhi context the term also, and perhaps most importantly, refers to the households (khangpa, khang pa) that are formally linked to a specific monastery. In today's world, it may sometimes also indicate the owner (patron) of a guesthouse or a restaurant. According to Kenneth Bauer, the term chindak also designates the clients of the amchi in the Dolpo region of Nepal, since those practitioners set no fixed price for

\footnotetext{
Note 20 Ladakhis were recognised in India as "Scheduled Tribes" in 1989. This is a socio-political category dating from the British colonial period. Read Xaxa (2003) for a general analysis and van Beek (1997) for a study of the process and social implications of the obtaining of this status in Ladakh.

Note 21 After twenty years of practice, an amchi may sit for the Smanrampa Chewa (sman rams pa che ba) examination according to the same principles (knowledge, practice and publications).

Note 22 For years, this amchi intended to establish his own structure in order to "dynamise amchi medicine in Ladakh", noticing especially in 2001 the lack of enthusiasm and the absence of activity of the main amchi association in Ladakh. It would seem that this project is now void since the man also became president of the main association of amchi in the region in autumn 2006, and director of the National Research Institute for Sowa Rigpa in 2011, a year after Tibetan medicine was granted official recognition in India. Today, he holds various prestigious positions within the amchi community.

Note 23 On renown in another Himalayan context, see the article by Sagant (1990).

Note 24 On the interaction between amchi in Ladakh, including Dolma Tsering, and their foreign patients, see Pordié (2011).
} 
consultation and treatment. They refer to their patients as chindak since they are free to procure financial or material contributions for the amchi (Bauer 2004: 34). In the Tibetan world, the act of giving, chinba (sbyin-pa) leads to the accumulation of merit, gewa (dge-ba), for one's personal salvation. Giving is socially valued. This act reflects the Tibetan altruistic approach that benefits both the author of the action and the recipient (bdag gzhan). The practice of donating (Skt. dāna) constitutes, from a doctrinal point of view, one of the six "perfections" (phar phyin, Skt. pāramitā) to be cultivated by one who follows the way of the Bodhisattva. ${ }^{25}$ It is also a social mechanism that makes it possible, among other things, to maintain one's membership of a given community. ${ }^{26}$ The donor's act is thus intimately connected with the identity of the group (Klieger 1992), so much so that Eberhard Berg (2003) interprets it, in a study carried out among the Sherpas, as fundamental in the construction of their identity. In Ladakh, household status related to chindak is essential for house identity and community membership.

Today, the term is also applied to organizations or individuals involved in some way with charity or development projects. Generally speaking, any foreigner, especially from the West, is considered as a potential donor. ${ }^{27}$ Foreigners are of three types: those belonging to professional organizations, members of informal associations or groups, and independent donors. The fascination the West has for the Tibetan world (Lopez 1998, Brauen 2004, Korom 2001), and the interest of our societies in alternative medicine in the last two or three decades are not unconnected with the establishment of such projects. Sponsored activities are numerous and heterogeneous, and are usually conducted following the advice of selected interlocutors, who are generally urban amchi participating in the NGO sector and benefiting, as does Dolma Tsering, from a high status within their community of practitioners.

A study of these projects brings to light a two-fold proximity between donors and the amchi of Ladakh. This consists, in the first place, of proximity of intervention: the projects are usually very localized, with donors visiting the places when they can. But proximity is expressed too in the social relationship that the donors enjoy with their "beneficiaries." Christiaan Klieger noted that the act of giving provides foreigners with the feeling of being in close touch with Tibetan society (1992: 136). And this closeness is all the more intense when the gift is repeated as in the case of individual sponsorships. The gift tends to strengthen the link between giver and recipient. In other words, the gift creates social links: the act of giving belongs to a social mechanism that links donor and receiver, a situation that leads to the establishment of a relationship of reciprocity. Amchi generally show their gratitude to donors by careful attentions and by reverential attitudes in both informal and official situations. Donors, actual or prospective, could expect to be offered a good place in the row ( $\mathrm{gral}$ ) during assemblies. ${ }^{28}$ Correspondence is exchanged between donors and recipients, and the relationship strengthens over time. When the donors possess the material means, individual or institutional, the amchi are sometimes invited to visit their benefactors' countries.

There starts a long and painful process for Himalayan people to be administratively cleared to travel to the West, Australia or to an economically advanced Asian country, which involves obtaining a passport for some and all the visa requirements, the modalities of which vary from country to country. When this step is over, donors are usually flattered to welcome a representative of the Tibetan world to their countries. The visit confirms the vitality of their project and their personal integration into their guest's country. For some, the act of receiving a traditional amchi demonstrates their enthusiasm for Tibetan medicine, and in some cases for Buddhism too. It is in this way, to paraphrase Jean-Loup Amselle (2001), that local peculiarities can be "plugged" into transnational networks. The invited amchi tour and give consultations and lectures which usually generate funds, both for themselves and for the projects or organizations that have invited them. In this manner the interests of all concerned converge.

\section{Fame, Money and their Social Impact}

The social ascent and the functions of Dolma Tsering have made her known to foreign donors. She went to London at the beginning of 2005 and practised medicine there for several months. She had developed a close relationship with an English donor who covered her travel and living expenses. She informed her NGO colleagues that she would stop her activities for this period; she closed her clinic and sent her patients to a nearby practitioner, and she flew to London. There, her benefactor organized a series of daily consultations. Dolma Tsering earned the equivalent of $\$ 130$ per patient - compared to the 30 to 120 rupees that she used to charge in Ladakh (the equivalent of 50 cents to $\$ 2$ ). As a consequence, she returned to her country quite prosperous. In her circles, and not excluding some of her close colleagues, her new affluence provoked a good many caustic comments, often in the guise of mean jokes.

\footnotetext{
Note 25 The Bodhisattva (being promised to Enlightenment) renounces nirvāna (or extinction, which marks the end of cyclic existence in saṃsāra) until all other beings have entered nirvāṇa before him. On this subject, see the translation by Batchelor of Shantideva's Bodhisattvacharyavatara (1979). Note 26 See, for example, the works by Jest (1975: 346) on Dolpo, and by Tucci and Heissig (1973: 371) on Tibet.

Note 27 This is similar to Prost's findings in Dharamsala (2005). However, this author noted that, among the Tibetan refugees, a particular type of relationship with the foreign donors has been established, the rogs ram. This is a new development of older forms of patronage and sponsorship, such as chindak, and specific to the exiles in India (see also Prost 2008: 62-66).

Note 28 On the placement in the row in Buddhist Ladakh, see Aggarwal (2004: 154-155), Kaplanian (1981: 171-190) and Pirie (2007: 48-50).
} 
She endured a similar experience the following year, after a few months in Goa, on India's west coast. Her next journey took her to France with two colleagues. During the month they spent in there, in the autumn of 2007, at the invitation of her European employer, she carried out a lecture tour of several major French towns. The group stayed on in Europe a few weeks longer as guests of some individual donors who had been contacted in advance. None of the three had become any richer after their trip, but the bare fact that they had been abroad was enough to stir up ill feeling among their fraternity in Ladakh.

The international mobility of the amchi complicates relations with others. This demonstrates how fraught the situation can be when a conspicuously successful individual is to be found in the context of a culture which frowns on too quick or too obvious an acquisition of wealth or status. This type of situation exists among the Tibetans in exile in Dharamsala too. The case of Lobsang Dolma Khangkar (1935-1989) provides a telling example. This amchi, who belongs to a renowned Tibetan lineage, had settled in India in 1961. She had joined the Men-Tsee-Khang in Dharamsala in 1972 at the invitation of the Tibetan authorities there and worked for six years in this institution. The standing and net worth of this amchi rose dramatically after she had established her private practice in McLeod Ganj, upper Dharamsala. Her international network of sympathizers supported her frequent stays in the West. The management of the Men-Tsee-Khang considered, however, that the woman was too interested in her personal enrichment and her career and decided to dismiss her: "With a selfish attitude that gave personal gain greater priority in her daily work, she disregarded the general rules and regulations of the employees of the medical centre (...) the members of the medical centre, after prolonged tolerance and understanding, unanimously resolved to suspend her from her present duty" (Tibetan Review 1978, cited by Tsering 2005: 183).

In another context, Evelyne Micollier showed that the international diffusion of qi gong was supported in the same way by the establishment of social networks (2004). She described this process as a phenomenon of "de-territorialisation" and "re-territorialisation". The worldwide spread of qi gong bestowed social capital upon the practice, not only internationally but also at the national level. This is similar to what we observe in those countries where Tibetan medicine is endemic or very ancient. Its international popularity gives it a new order of legitimacy on the national level. In Ladakh, individual participation in the NGO sector confers an enhanced social status upon the amchi, both in their therapeutic community and beyond, and travel further reinforces this status. ${ }^{29}$ As much as the local social ascent of Dolma Tsering has made her known to donors, her association with foreign donors has contributed to strengthening her social status. The process is circular. However, bringing the analysis to a close at this point would leave us with barely more than a partial view of the Ladakhi situation. More than simply consolidating status, international travel and the making of money also bring in their wake ambivalence for the individuals concerned.

It must be made clear that not all amchi travel. In only involving members of the amchi elite, foreign travel plays a significant role in the mechanisms of reproduction and consolidation of social status. The picture becomes more complicated when we go on to look at the local repercussions of the global circulation of amchi. Those therapists who spend time abroad undergo the same type of experience as Dolma Tsering. Accusations of opportunism, greed or boastfulness inevitably arise in a cultural milieu where these qualities are normally proscribed.

Amongst the Ladakhi amchi elite, the interpersonal tensions that emerge in circumstances such as those described above, are all the more salient given that their group is limited to a small number of members who, moreover, maintain relatively difficult relationships (Pordié 2008b). Disagreements are commonplace, and antagonisms are sometimes very vehement. ${ }^{30}$ Conflicts are rendered almost invisible by local codes of decorum (Pirie 2007), but they exist in some number and persist. Therefore, by joining the amchi elite, Dolma Tsering has been confronted with a competitive arena animated by vibrant rivalries. Her travels have occasioned various difficult remarks, often containing moral judgements, on the part of other amchi. The gradual integration of Dolma Tsering into the medical elite of Ladakh has thus bound her to the rules of that group.

Dolma Tsering clarifies today that the money earned during her travels has been partly used to buy two machines for the production of medicines. From her point of view, she thus contributes to the preservation of traditional pharmaceutical knowledge, which not all amchi can be said to retain (Blaikie 2013). This position allows her to distinguish herself from other therapists whose practice is limited to diagnosis and treatment. She underscores the fact that her knowledge also concerns the domain of pharmacy, and that she is able to make her own medicines.

If some amchi shy away from revealing their travel plans, particularly when a foreign trip is involved, they only do so in

Note 29 Amongst the amchi of Ladakh the types of social legitimacy are numerous and overlapping. The most important modes of legitimization are belonging to practitioners' lineages, having obtained all or part of one's medical education in Tibet, individual moral qualities, the perceived efficacy of the medicine, institutional education, government functions and the management of associations (Pordié, 2001). Foreign travel holds a special place in this classification, for those who benefit from it often combine several of these modes of legitimization.

Note 30 This type of situation is noted elsewhere, amongst Tibetan exiles in India and in the United States (Tokar 2008: 243-244). 
order to avoid possibly painful consequences, such as those Dolma Tsering and others have experienced. A Government amchi in Ladakh and member of the elite thus kept quiet for weeks on end regarding one of his journeys abroad in November 2002. Several rumours about him were going round: he was in Delhi, Calcutta, Dharamsala, Kathmandu, in the West... no one really knew for certain where. Everyone however mobilised his own network - kin in Delhi, foreign donors or associations - to explain the sudden "disappearance" of the subject. The amchi had, in fact, gone to France and had concealed his journey so as to avoid, as he told me, the jealousy and disparaging remarks his confreres were bound to hurl at him. ${ }^{31}$

Do the amchi always travel to the West? Certainly not. One of them was, for example, invited by a Japanese donor to go to Lhasa in July 2000 to participate in a conference on Tibetan medicine. This amchi envisaged visiting the famous Potala - the dream of every Buddhist Ladakhi. His joy at the prospect was very apparent. I followed him on his journey that took us first to Kathmandu from where, together with a group of Nepalese amchi, we were to proceed to Lhasa. Unfortunately, he was refused a visa. According to the Nepalese, the presence of a Tibetan name on an Indian passport had led the Chinese authorities to reject his application. But this rule is not always verified and there probably were other circumstances that led the authorities to deny entry to the Ladakhi. Insensitive to the man's distress, one of the Nepalese amchi came at once to visit him, opening before his eyes the pages of his own passport crammed with visas. He was a well reputed amchi of a remote region of Nepal who held job functions rather like those of the Ladakhi amchi in his own country. The Ladakhi amchi felt powerless seeing that this man had already been to Tibet, and had a five-year visa for the United States. The Nepalese amchi proudly explained that he travelled the world and gave teachings on medicine and religion in universities in the West. He added that his reputation "reached even as far as Lhasa". His many journeys attested to his status, while the Ladakhi amchi's inability to travel alongside the Nepalese showed him in up a poor light. By boasting of his own renown, the Nepalese amchi, however, had questioned his fellow amchi's reputation.

Interestingly, the Nepalese amchi had had difficulties of his own within his community of practitioners. ${ }^{32}$ One of the most severe conflicts that had led to a confrontation with the other amchi of Nepal had taken place in 2001-2002, when he returned quite prosperous from the United States. The members of the practitioner elite hoped that he would contribute part of his earnings towards the development of their medical system in the country. They could not have been more mistaken. Their confrontation culminated in 2002 with him being stripped of his chairman title from the national amchi association of which he had been the chairman since its inception in 1998.

The international mobility of therapists clearly has multiple ramifications. It does not only enhance the status of individuals and the practice itself, it also tends to harm relationships within the practitioner community in the country.

\section{Conclusion}

It was by examining the various dimensions of the social and economic conditions governing access to the Ladakhi amchi elite that we discovered how Dolma Tsering, the young nomad girl from the high Himalayan plateaus, has become one of the most visible doctors in the region. Her gradual entry into the Tibetan medical NGO sector in Ladakh has allowed her to achieve a high status, an indispensable prerequisite for international travel. This article has thus revealed one important "pattern of mobility" (Hsu 2012) in the study of global Asian medical practitioners. Their new encounters, and the journeys that result from them, have clear social repercussions. These repercussions shape individual itineraries whilst opening a transnational space that reinforces their social status, and occasionally guarantee supplementary resources, and, for precisely these reasons, complicate their relationships with their confreres. While the phenomenon affects a relatively small group of Ladakhi practitioners, it is no less pertinent to the study of the social mechanisms involved in the global diffusion of Tibetan medicine.

Because international travel is perceived to be linked to the acquisition of fame and money, this mobility is experienced and managed through series of ruptures, differences and contestations. Travel, wrote James Clifford (1997), is an opening into a complex modernity. These frictions are amplified by the rapid changes brought about by development in the region which, together with the renewed aspirations of the amchi, tend to transform social relations. Furthermore, Fernanda Pirie (2007: 40) noted that "patterns of power, authority and influence in contemporary Ladakh are [complicated by] the introduction of new forms of wealth." The case of Dolma Tsering is a testimony to this: local

\footnotetext{
Note 31 Ladakhis also believe that they could become victims of the jealousy of others. They then find themselves under the influence of mikha $(m i$ $k h a$ ). These beings personify the "envious words of others" ( $m i$ means people, persons, and kha, mouth and word/s) aimed at whatever is beautiful, rich and new. They can cause ill fortune, including illness (Kaplanian 1981: 221). These "words" are not, however, explicitly aimed at doing harm. The mikha consists of the fact of talking a great deal about someone in terms of his qualities or of facts about him that support envy. It refers in this context to a form of "gossip" (Pirie, 2006: 188), and not necessarily to "malicious gossip" (Kapstein 1997: 527).

Note 32 This amchi had served as a case study in a work discussing altruism in the Tibetan world (Silhé 1995), even though it is precisely for the absence of this quality that many Nepalese therapists reproach him today. It is not improbable that the remarkable itinerary of this man had modified his behaviour. Some aspects of this man's life can also be found in an excellent book by Craig (2012).
} 
development, her rising authority and international journeys brought an effective or virtual wealth for which she was reproached, sometimes loudly. In this way, mobility not only brings a territorial but also a social disconnection. These disconnections are not necessarily absolute: travel never lasts forever and the conflicts that result in Ladakh are private and relatively minor. But, conflicts are judged harmful for social equilibrium (Pirie 2007). The amchi feel shame, trelba (khrel ba) when their differences are known to outer circles. In all cases the conflicts are kept within a delineated perimeter.

There are other significant factors related to individual identity in the way this story unfolded. The first concerns gender politics, understood as the place of gender in broader configurations of meaning, interaction, and power. In a male-dominated environment, the achievements of Dolma Tsering, a distinct cultural actor, are remarkable. She is the most established and a truly recognised female practitioner in the region and her efforts came up against many hurdles that both her competencies and determination helped to cross. Feminist studies would see here a dynamic of resistance (Collier and Yanagisako 1989), informed by the way Dolma Tsering behaved and subsequently gained credit in the real world (Conkey and Gero 1997). Her actions provided the ground from which her critics have formulated their grievance, underscoring in this case the nature of right and wrong and therefore involving morality. Indeed, for populations of Tibetan culture, the moral sphere is directly concerned with the way in which people act.

The focus on identity and difference also encourages examination of the meaning of other categories of social life and how they interact. Ethnicity appears to be a relevant analytical category as shown by the difficult relations between Tibetans and Ladakhis. The fact that Dolma Tsering is Tibetan was an impediment which certainly delayed her social ascent. Her origin was used in many occasions to prevent her accessing coveted positions within her fraternity. Her will and mastery of Tibetan medicine finally convinced all those against her to accept her presence among them, recalling Marx's suggestion that all social activity comes down to praxis.

In this case the idea of practice is twofold: we should consider the medical practice per se of a woman doctor of Tibetan medicine, as well as her social practices. In the latter case, acknowledging variations caused by a supplementary category such as age constitutes a rich terrain from which to observe generational differences in terms of life choices and social practices. Dolma Tsering belongs to the younger generation of amchi, she is an open and emancipated woman who is not afraid to walk off the beaten path. She belongs to a new, entrepreneurial generation of institutional amchi who bring Tibetan medicine to the world and are partly responsible for its future. Amidst all jealousies and ill feelings, these practitioners embody a prized form of social success. They renew the image of Tibetan medicine and bring to it a general dynamism that many practitioners consider favourable. As everywhere else in the Tibetan world, the urban form of Tibetan medicine represented by therapists such as Dolma Tsering is asserting its model as the best way to go forwards, as the ineluctable future.

This paper has also shown that not only is social status an important component of analysis but that we should also consider the importance of power, since the construction and enactment of identity occurs through discourses and actions that are structured by contexts of hierarchies and power (Geller and Stockett 2006, Pordié 2008b). In the male-centric, hierarchical world of the amchi, the accusations and problematic sentiments that arose among Dolma Tsering's peers as she quickly gained fame and money reflect these issues. They also demonstrate the continual dialogue between mobility and power (Langwick et al. 2012). From being refused prominent positions close to central power structures (as with the Research Unit), the situation was turned upside down as her status increased since she was then requested to take up various responsibilities. She refused, and therefore exerted a form of power through social relations. By entering transnational networks, this woman allowed us to see how individual agency and social structure in Ladakh unfold in the context of contemporary globalization. Her global mobility generates social frictions (Appadurai 1990, Tsing 2004), inherent to global connectedness and manifested on the ground as relational disjuncture.

\section{References}

Abélès, M. (1995). Pour une anthropologie des institutions, L'Homme, 135, XXXV, 65-85.

Adams, V. (2002). Randomized controlled crime: postcolonial sciences in alternative medicine research, Social Studies of Science, 32(5), 659-690.

Aggarwal, R. (2004). Beyond Lines of Control: Performance and Politics on the Disputed Borders of Ladakh, India, Durham, NC: Duke University Press.

Amselle, J. L. (2001). Branchements. Anthropologie de l'universalité des cultures, Paris: Champs Flammarion.

Appadurai A. (1990). Disjuncture and Difference in the Global Cultural Economy, Public Culture, 2(2), 1-24.

Aschoff, J. C., \& Tashigang, T.Y. (1997). On mercury in Tibetan "precious pills", Journal of the European Ayurvedic Society, 5, 129-135. 
Augé, M. (1994). Pour une anthropologie des mondes contemporains, Paris: Flammarion.

Avedon, J. F. (1997 [1984]). In Exile From the Land of Snows. The Dalaï Lama and Tibet since the Chinese Conquest, New Delhi: Penguin Books.

Batchelor, S. (1979). A Guide to the Bodhisattva's Way of Life [transl. of Shantideva's Bodhisattvacaryavatara], Dharamsala: Library of Tibetan Works and Archives.

Bauer, K. M. (2004). High Frontiers. Dolpo and the changing world of Himalayan pastoralists, New York: Columbia University Press.

Berg, E. (2003). Dumji and Zhindak. Local festival performance and patronage as a crucial source of Sherpa identity, in M. Lecomte-Tilouine and P. Dollfus (eds.), Ethnic revival and religious turmoil. Identities and representations in the Himalayas, New Delhi: Oxford University Press.

Besch, F. (2007). Making a medical living. On the monetisation of Tibetan medicine in Spiti, in Mona Schrempf (ed.), Soundings in Tibetan Medicine. Anthropological and Historical Perspectives, Leiden: Brill.

Besch, F. (2006). Tibetan Medicine Off the Roads. Modernizing the Work of the Amchi in Spiti, Ph.D. Dissertation, Heidelberg University.

Blaikie, C. (2013). Currents of tradition in Sowa Rigpa pharmacy, East Asian Science, Technology and Society, 7(3), 425-451.

Blaikie, C. (2009). Critically endangered. Medicinal plant cultivation and the reconfiguration of Sowa Rigpa in Ladakh, Asian Medicine, 5(2), 243-272.

Brauen, M. (2004). Dreamworld Tibet, Western Illusions, Trumbull, CT: Weatherhill.

Chauhan, H. (2007). Don't commercialise Tibetan medicines, says PM in exile, Phayul.com, url: http://www.phayul.com/mobile/?page=view\&c=1\&id=15243.

Clifford, J. (1997). Routes. Travel and Translation in the Late Twentieth Century, Cambridge, MA: Harvard University Press.

Collier, J., \& Yanagisako, S. (1989). Theory in Anthropology since Feminist Practice, Critique of Anthropology, 9(2), 27-37.

Conkey, M., \& Gero, J. (1997). Programme to Practice: Gender and Feminism in Archeology, Annual Review of Anthropology, 26, 411-437.

Craig, S. (2012). Healing Elements: Efficacy and the Social Ecologies of Tibetan Medicine, Berkeley: University of California Press.

Craig, S., \& Adams, V. (2008). Global Pharma in the Land of Snows. Tibetan medicines, SARS, and identity politics across nations, Asian Medicine, 4(1), 1-28.

Dolffus, P. (2004). Vers une sédentarisation univoque ? Le cas des éleveurs nomades de Kharnak, Ladakh, Himalaya Occidental Indian, Nomadic People, 8(2), 200-213.

Farquhar, J., \& Lai, L. (2004). Institution and the Wild: Salvaging and Sorting Minority Medicines in China, paper given at the Chicago Center for Contemporary Theory, 14 October.

Froystad, K. (2009). The Return Path: Anthropology of a Western Yogi, in T. J. Csordas (ed.), Transnational Transcendence: Essays on Religion and Globalization, Berkeley: University of California Press.

Geller, P., \& Stockett, M. (2006). Feminist Anthropology: Past, Present, and Future, Philadelphia: University of Pennsylvania Press.

Goodall, S. (2004). Rural-to-urban migration and urbanization in Leh, Ladakh: a case study of three nomadic pastoral communities, Mountain Research and Development, 24, 220-227.

Hsu, E. (2012). Mobility and connectedness: Chinese medical doctors in Kenya, in H. Dilger, A. Kane \& S. Langwick (eds.), Medicine, Mobility and Power in Global Africa. Transnational Health and Healing, Bloomington: Indiana University Press.

Janes, C. R. (2002). Buddhism, Science, and Market: The Globalization of Tibetan Medicine, Anthropology and Medicine, 9(3), 267-289.

Janes, C. R. (2001). Tibetan medicine at the crossroads : radical modernity and the social organisation of traditional medicine in the Tibet Autonomous Region, China, in L. H. Connor and G. Samuel (eds.), Healing Powers and Modernity. Traditional Medicine, Shamanism and Science in Asian Societies, Westport, CT - London: Bergin \& 
Garvey.

Janes, C. R. (1995). The transformations of Tibetan Medicine, Medical Anthropology Quarterly, 9(1), 6-39.

Janes, C. R., \& Hilliard, C. (2008). Inventing tradition: Tibetan medicine in the post-socialist contexts of China and Mongolia, in L. Pordié (ed.), Tibetan Medicine in the Contemporary World. Global Politics of Medical Knowledge and Practice, London \& New York: Routledge.

Jest, C. (1975). Dolpo : Communautés de langue tibétaine du Népal, Paris: Editions du CNRS.

Josayma, T. T., \& Dhondup, K. (1990). Dolma and Dolkar: Mother and Daughter of Tibetan Medicine. Delhi: Yarlung.

Kaplanian, P. (1981). Les Ladakhis du Cachemire, Paris: Hachette.

Kapstein, M. (1997). Turning back gossip, in D. Lopez (ed.), Religions of Tibet in Practice, Princeton: Princeton University Press.

Klieger, C. (1992). Tibetan Nationalism: The Role of Patronage in the Accomplishment of National Identity, Meerut: Archana.

Kloos, S. (2013). How Tibetan medicine in exile became a "Medical System", East Asian Science, Technology and Society, 7(3), 381-395.

Kloos, S. (2010). Tibetan Medicine in Exile: The Ethics, Politics and Science of Cultural Survival, PhD thesis, University of California, San Francisco and Berkeley.

Kloos, S. (2008). The history and development of Tibetan medicine in exile, Tibet Journal, 33(3), 15-49.

Korom, F. J. (2001). The role of Tibet in the New Age movement, in T. Dodin \& H. Räther (eds.). Imagining Tibet. Peceptions, Projections and Fantaisies, Boston: Wisdom Publications.

Kuhn, A. (1994). Ladakh: A Pluralistic Medical System under Acculturation and Domination, in D. Sich \& W. Gottschalk (eds.), Acculturation and Domination in Traditional Asian Medical Systems, Stuttgart: F. Steiner Verlag Stuttgart.

Langwick, S., Dilger, H., \& Kane, A. (2012). Introduction: Transnational Medicine, Mobile Expert, in H. Dilger, A. Kane \& S. Langwick (eds.), Medicine, Mobility, and Power in Global Africa. Transnational Health and Healing, Philapdelphia: Indian University Press.

Lopez, D. (1998). Prisoners of Shangri-la: Tibetan Buddhism and the West, Chicago: University of Chicago Press.

Meyer, F. (1995). Theory and practice of Tibetan Medicine, in J. V. Alphen, A. Aris (eds.), Oriental Medicine, An Illustrated Guide to the Asian Arts of Healing, Serindia Publications (re-edited by Shambala Publ., Boston, 1997).

Meyer, F. (1986). Orient-Occident : un dialogue singulier, in F. Bouchayer (ed.), Autres médecines, autres mours. L'explosion des nouvelles techniques de santé, Paris: Editions Autrement.

Micollier, E. (2004). Le qigong chinois : enjeux économiques et transnationalisation des réseaux, pratiques et croyances, Journal des Anthropologues, 98-99, 107-146.

Michaud, J. (1990). Mais entrez donc! Les entrepreneurs touristiques et le pouvoir au Ladakh (Inde). Anthropologie et Sociétés, 14(3), 127-139.

Millard, C. (2008). The integration of Tibetan medicine in the United Kingdom: The clinics of the Tara Institute of Medicine, in L. Pordié (ed.), Tibetan Medicine in the Contemporary World. Global Politics of Medical Knowledge and Practice, London and New York: Routledge.

Pirie, F. (2007). Peace and conflict in Ladakh: the construction of a fragile web of order. Leiden: Brill.

Pirie, F. (2006). Secular morality, village law, and Buddhism in Tibetan societies, Journal of the Royal Anthropological Institute, 12, 173-190.

Pordié, L. (2015). Genealogy and ambivalence of a therapeutic heterodoxy. Islam and Tibetan medicine in North-western India, Modern Asian Studies, 49(6), 1772-1807.

Pordié, L. (2011). Accentuations et pragmatismes. Le savoir médical tibétain à destination des étrangers, Revue d'Anthropologie des Connaissances, 5(1), 99-130.

Pordié, L. (2008a). Tibetan medicine today. Neo-traditionalism as an analytical lens and a political tool, in L. Pordié (ed.), Tibetan Medicine in the Contemporary World. Global Politics of Medical Knowledge and Practice, London and New York: Routledge.

Pordié, L. (2008b). Hijacking intellectual property rights. Identities and power in the Indian Himalayas, in L. Pordié (ed.), Tibetan Medicine in the Contemporary World. Global Politics of Medical Knowledge and Practice, London 
and New York: Routledge.

Pordié, L. (2007). Buddhism in the everyday medical practice of the Ladakhi amchi, Indian Anthropologist, 37(1), 93-116.

Pordié, L. (2002). La pharmacopée comme expression de société. Une étude himalayenne, in J. Fleurentin \& G. Mazars and J. M. Pelt (eds), Des sources du savoir aux médicaments du futur, Paris: Editions de l'IRD.

Pordié, L. (2001). The logics of legitimization among the amchi of Ladakh, paper presented at the $X^{\text {th }}$ Colloquim of the IALS, Oxford University, September.

Pordié, L., \& Blaikie, C. (2014). Knowledge and skill in motion. Layers of Tibetan medical education in India, Culture, Medicine \& Psychiatry, 38(3), 340-368.

Prost, A. (2008). Precious Pills. Medicine and Social Change among Tibetan Refugees in India, Oxford: Berghahn Books.

Prost, A. (2006). The problem with 'rich refugees'. Sponsorship, capital and the informal economy of Tibetan refugees, Modern Asian Studies, 40(1), 233-254

Sagant, P. (1990). Les Tambours de Nyi-shang (Népal), Rituel et centralisation politique, in Tibet. Civilisation et société, Paris : Editions de la Maison des Sciences de l'Homme / Fondation Singer-Polignac.

Samuel, G. (2001). Tibetan Medicine in Contemporary India, Theory and Practice. in L. H. Connor \& G. Samuel (eds.), Healing Powers and Modernity, Traditional Medicine, Shamanism and Science in Asian Societies, Westport, Connecticut - London: Bergin \& Garvey.

Saxer, M. (2013). Manufacturing Tibetan Medicine. The Creation of an Industry and the Moral Economy of Tibetanness, Oxford: Berghahn Books.

Saxer, M. (2010). Tibetan medicine and Russian modernities, in V. Adams, S. Craig, \&d M. Schrempf (eds.), Medicine between Science and religion. Exploration on Tibetan Grounds, Oxford: Berghahn Books.

Saxer, M. (2005). Journeys with Tibetan Medicine. DVD, Suisse (Docufaktory), $76 \mathrm{~min}$.

Saxer, M. (2004). Journeys with Tibetan Medicine. How Tibetan Medicine Came to the West. The Story of the Badmayev Family, MA Thesis, Institute of Social and Cultural Anthropology, University of Zürich.

Sihlé, N. (1995). "Pour le bien des êtres et de la doctrine ». L'action altruiste dans la culture tibétaine à travers l'exemple du religieux et médecin Ts'ampa Ngawang (Jomsom, Nord du Népal), Mémoire de DEA, Département d'Ethnologie et de Sociologie Comparative, Université de Paris X - Nanterre.

Tokar, E. (2008). An ancient medicine in a new world: a Tibetan medicine doctor's reflections from "inside", in L. Pordié (ed.), Tibetan Medicine in the Contemporary World. Global Politics of Medical Knowledge and Practice, London and New York: Routledge.

Tsering, T. (2005). Outstanding women in Tibetan medicine, in J. Gyatso \& H. Havnevik (eds.), Women in Tibet, New York: Columbia University Press.

Tsing, A. L. (2004). Friction. An Ethnography of Global Connection, Princeton: Princeton University Press.

Tucci, G., \& Heissig, W. (1973). Les religions du Tibet et de la Mongolie, Paris: Payot.

van Beek, M. (1997). The importance of being tribal, or: the impossibility of being Ladakhis, in T. Dodin \& H. Räther (eds.), Recent Research on Ladakh, Vol. 7, Ulm: Ulmerkulturanthrpologishe Scriften.

Vargas, I. (2008). Tibetan medicine revisited in the West. Notes on the integrative efforts and transformative consequences occurring in Massachusetts, USA, in L. Pordié (ed.), Tibetan Medicine in the Contemporary World. Global Politics of Medical Knowledge and Practice, London and New York: Routledge.

Wylie, T. V. (1959). A standard system of Tibetan transcription, Harvard Journal of Asiatic Studies, 22, 261-276.

Xaxa, V. (2003). Tribes in India, in V. Das (ed.), The Oxford Indian Companion to Sociology and Social Anthropology, 2 Vol., New Delhi: Oxford University Press.

Zhan, M. (2009). Other-Worldly: Making Chinese Medicine Through Transnational Frames, Durham, NC: Duke University Press.

\section{$(\mathrm{cc}) \mathrm{BY}$}

This work is licensed under a Creative Commons Attribution 3.0 License. 